\title{
COVID-19: Hava Yolu ile Bulașıyor mu?
}

\section{COVID-19: is it Airborne?}

\author{
Gül Ruhsar YILMAZ'1(ID)
}

${ }^{1}$ Süleyman Demirel Üniversitesi Tıp Fakültesi, İnfeksiyon Hastalıkıarı ve Klinik Mikrobiyoloji Anabilim Dalı, Isparta, Türkiye

Makale atıfi: YIImaz GR. COVID-19: hava yolu ile bulaşıyor mu? FLORA 2020;25(4):464-73.

ÖZ

Maske, mesafe ve hijyen; SARS-CoV-2 infeksiyonundan korunmak için başta gelen önlemler olarak uygulanmaktadır. Pandeminin başında virüsün öncelikle damlacıkla, aerosolizasyon oluşturan medikal işlemler sırasında da aerosolle bulaştığı düşünülmüştür. Ancak daha sonra yayımlanan vaka kümelenmeleri, kapalı ve havalandırması kötü ortamlarda virüsün aerosol yolu ile de bulaştığına işaret etmiştir. Bu yazıda SARS-CoV-2'nin aerosolle bulaşını destekleyen deneysel ve epidemiyolojik veriler ele alınmıştır.

Anahtar Kelimeler: COVID-19; SARS-CoV-2; Aerosol; Bulaş

\section{ABSTRACT}

\section{COVID-19: is it Airborne?}

\author{
Gül Ruhsar YILMAZ1
}

\footnotetext{
${ }^{1}$ Department of Infectious Diseases and Clinical Microbiology, Suleyman Demirel University, Isparta, Turkey
}

\begin{abstract}
Mask, social distancing, and hygiene are followed as primary precautions in order to be protected from the SARS-CoV-2 infection. At the beginning of the pandemic, the virus was considered to be transmitted by droplets and aerosols during medical procedures generating aerosolization. However, case clusters published later on proved that the virus was also transmitted by aerosols in indoors and in settings with bad ventilation. This study aimed to discuss the experimental and epidemiological data supporting aerosol transmission of SARS-COV-2.
\end{abstract}

Key Words: COVID-19; SARS-CoV-2; Aerosol; Transmission 


\section{GiRiş}

Ilk kez Aralı 2019'da Cin'in Wuhan eyaletinden bildirilen SARS-CoV-2 infeksiyonu, takip eden dönemde hızla dünyaya yayılmıs ve pandemi haline gelmiștir. Vaka ve ölüm sayısı 11 Aralı 2020 itibariyle 68845368 ve 1570304 olarak bildirilmistirir ${ }^{[1]}$.

Çoğu bilim insanına göre SARS-CoV-2 bulașından damlacıklar sorumlu olup arastırmaların çŏu bu konuda daha iyi bilgi toplamaya odaklanmıștır. Ancak aerosollerin de hastalığın bulașında majör bir rol oynayabileceği endișesi pandeminin bașından beri gündeme getirilmektedir. Damlacık ve aerosol yoluyla bulas arasında ayrm yapabilen net bir calıșma yoktur. Aerosolle bulas konusunda bilim insanları arasında iki ayrı görüs söz konusudur ${ }^{[2]}$. İlki COVID-19'da damlacık bulașının daha baskın olduğu ancak aerosolizasyon olușturan ișlemler sırasında aerosollerin de bulașta rol oynayabileceği iken, diğer görüș yalnızca nefes alma ve konusma sırasında bile aerosollerin olușbileceği, bu nedenle COVID-19'un önlenmesi için damlacık önlemleri yanı sıra hava yolu önlemlerinin de alınması gerektiği seklindedir.

Dünya Sağllk Örgütü (DSÖ) ve Amerika Hastalik Kontrol ve Korunma Merkezi (CDC) 5 um'den büyük partikülleri damlacık, $\leq 5 \mu \mathrm{m}$ olanları aerosol ya da damlacık cekirdeği olarak tanımlamaktadır $^{[3,4]}$. Genellikle 5-10 $\mu$ m'den kücük, havadaki patojen yüklü partiküller infeksiyöz aerosol olarak isimlendirilmektedir.

10-20 $\mu \mathrm{m}$ çaptaki partiküllerin de havada uzun süre asılı kalmaları ve akciğerde alveoler bölge- ye ulaşabilmeleri nedeniyle aerosol kabul edilmesi gerektiği iddiaları vardır. Potansiyel bulaș yolları açısından kanıtlar sınırlı olduğu için CDC tarafından SARS-CoV 2'nin diğer insan koronavirüsleri gibi yayıldığı farz edilmektedir ${ }^{[5-7]}$.

Aerodinami cerçevesinde $<10 \mu \mathrm{m}$ partiküller için havanın kaldırma kuvveti yerçekimi kuvvetinden daha fazladir. Bu nedenle bu partiküller uzak mesafelere ulașabilirler. Büyüklüğü 10-50 $\mu \mathrm{m}$ olan partiküller için ise havanın kaldırma kuvveti yerçekimi kuvvetine eșit olup kısa bir mesafe için sürüklenme kuvveti etkilidir. Daha büyük partiküller üzerinde yerçekimi kuvveti havanın kaldırma kuvvetinden daha fazla olduğundan bunlar yere doğru hareket ederler. Hava akım hızı ne kadar yüksekse kaldırma kuvveti de o kadar fazladır (Sekil 1) [8]. Damlacık olarak tanımlanan partiküllerin \%90'1 su olup; kaynaktan atıldıktan sonra suyun buharlașması ile hızla boyut kaybetmekte, bașlangıctaki büyüklüklerinin \%20-40'ı kadar kalmakta ve inhale edilebilir damlacık cekirdeği haline gelmektedir.

Öksürük akımı ile olușan türbülans yoluyla ekspiratuvar damlacıkların yayılımının simülasyonuna bakıldığında, büyük partikül ya da damlacıkların kaynağın yakınına düștüğü, orta büyüklükteki partikül veya damlacıkların horizontal olarak daha ileriye düștüğu, küçük partiküllerin ise havada asılı kaldıkları matematiksel modelleme ile de gösterilmiștir (Sekil 2). Bu simülasyona göre temas, damlacık ve aerosol ile bulașa yol açan infeksiyöz partiküller Sekil 3'te gösterilmiștir.

COVID-19 öncesi infeksiyon kontrol ve önleme stratejilerinde cut-off değeri $5 \mu \mathrm{m}$ kabul edi-

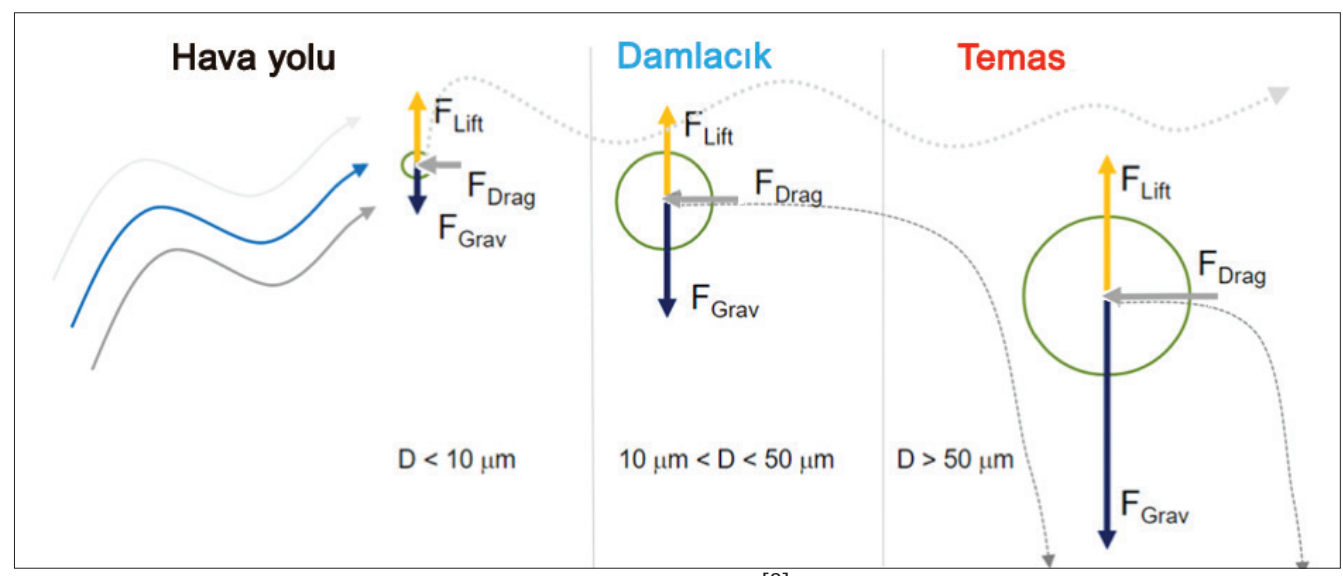

Şekil 1. Büyüklüklerine bağlı olarak havada partiküllerin yönü[8]. 


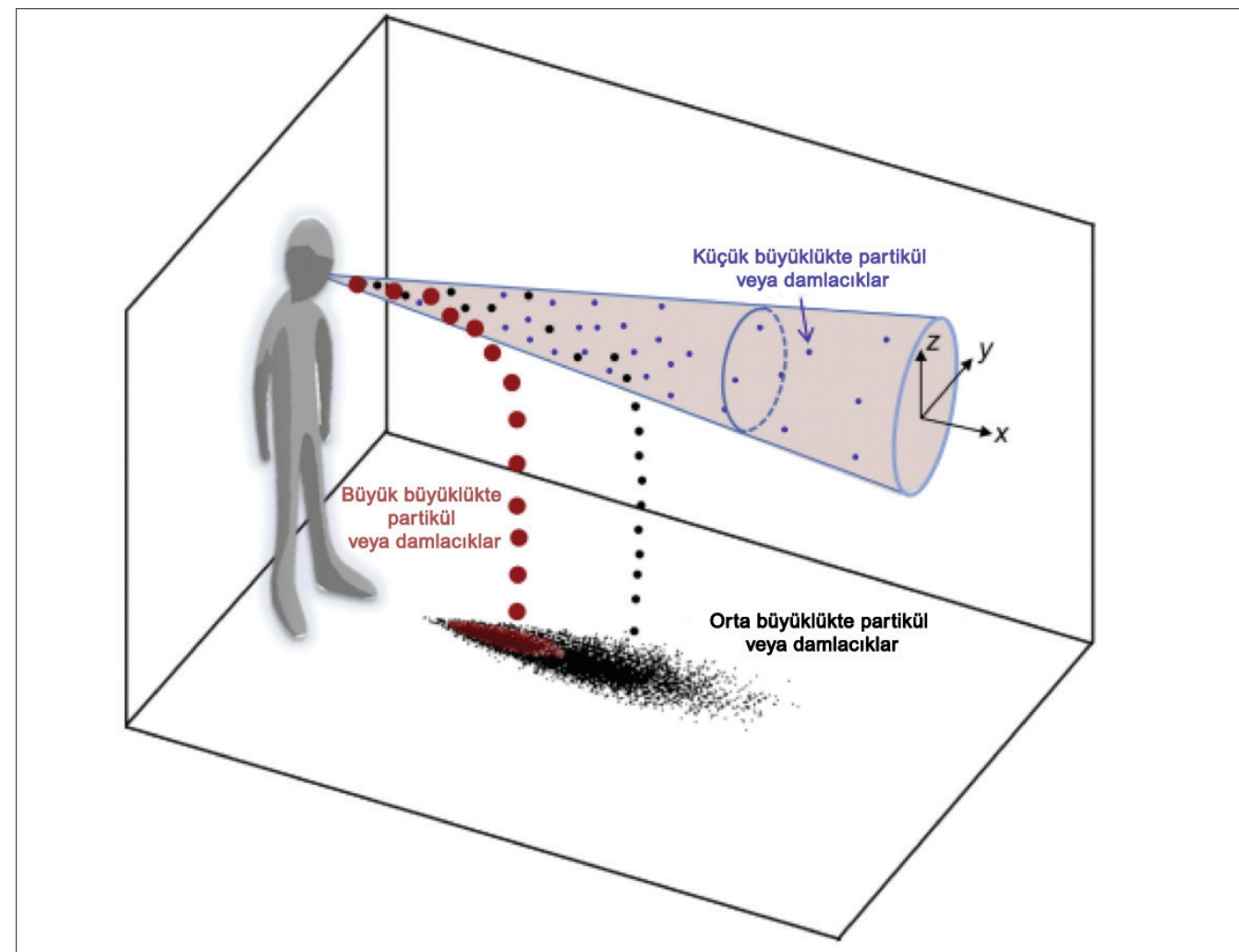

Şekil 2. Öksürük akımı ile oluşan türbülans yoluyla ekspiratuvar damlacıkların yayılımının simülasyonu[9]

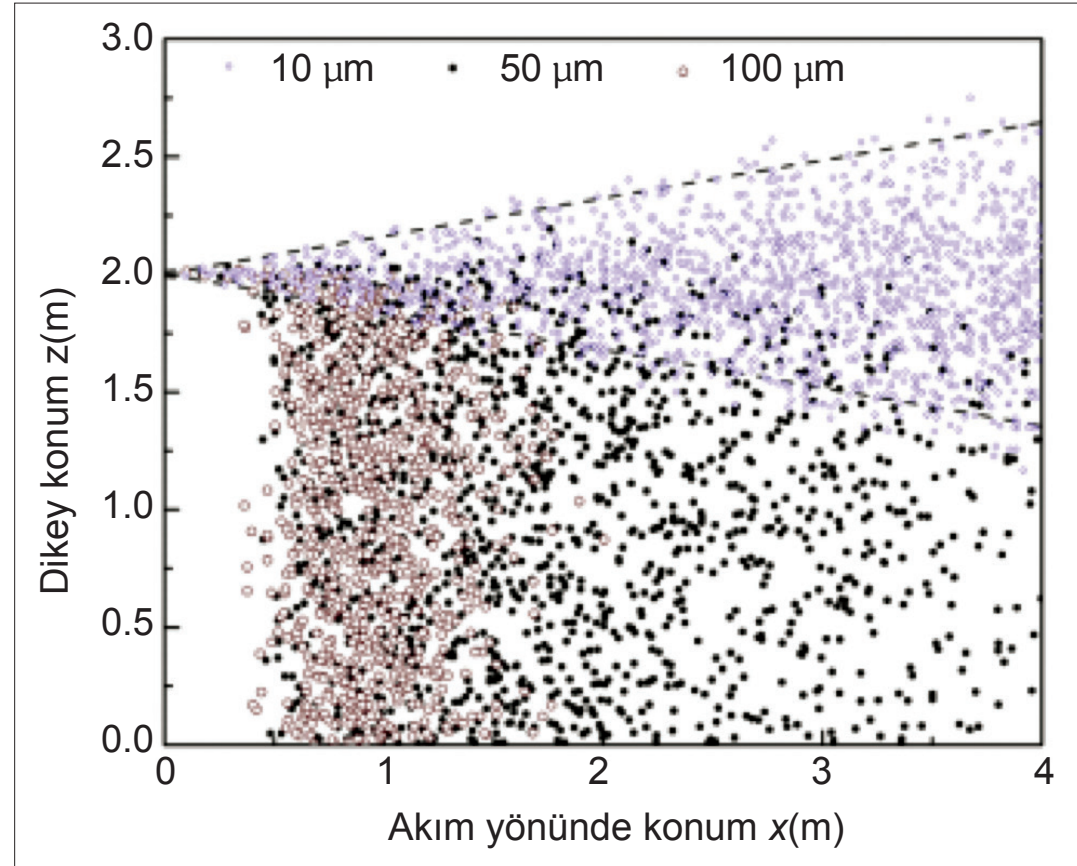

Şekil 3. Partiküllerin $10 \mathrm{~m} / \mathrm{s}$ hızla akış yönünde anlık dağılımı ${ }^{[9]}$. 
lerek küçük ve büyük damlacıklar arasında kesin bir ayrım olduğu varsayılmıștır. Oysa damlacıkların hızla buharlașarak damlacık çekirdekleri haline gelmeleri bu ayrımın doğru olmadığına ișaret etmektedir. İnfekte kișiden damlacık yoluyla atılan virüsün duyarlı konağın ağız, burun ya da gözüne ulașması ihtimalinin, aerosol yoluyla cok sayıda kücuik partikülün inhalasyonu ihtimalinden daha düșük olduğu iddia edilmektedir. Yakın mesafede bulas riskinin yüksek olduğu iddiasının damlacıkların bulașta daha baskın olduğunu gösterip aerosol ile bulaș tezini cuiruitmeyeceği belirtilmektedir ${ }^{[10]}$.

Aerosolle bulaș konusunda DSÖ tarafından farklı mesajlar verilmiștir. Salgının ikinci ayında (11 Şubat 2020) DSÖ, SARS-CoV-2'nin aerosol yolu ile bulaștığını açıklamıștır ${ }^{[11]}$. Mart sonunda ise DSÖ tarafindan COVID-19'un esas olarak damlacık yoluyla bulaștığı açıklanmıștır ${ }^{[12]}$. Aynı kurum tarafindan 9 Temmuz'da yapilan açıklamada ise bazı salgin raporlarının olası aerosol bulașına ișaret ettiği bildirilmiștir ${ }^{[13]}$. Bu açıklamadan üc gün öncesinde (6 Temmuz 2020) Morawska ve Wilson tarafından hava bilimciler, hekimler, epidemiyologlar ve mühendislerin dahil olduğu 237 bilim insanının imzasını içeren bir mektupla ulusal ve uluslararası kurulușlara SARSCoV-2'nin havayolu ile potansiyel bulașı konusu ile ilgili çağrı yapılmıștır ${ }^{[14]}$. Dünya Sağlık Örgütui 9 Temmuz'da yayımladığı bildiride, aerosolle bulașın olasılığı ile ilgili daha fazla araștırma gerektiğini, kalabalık ve havalandırması kötü olan yerlerde aerosolle bulașın ekarte edilemeyeceğini bildirmistir [13]

\section{Hava Yolu Bulașı Yönüinde Bilgi ve Kanitlar}

Hasta odalarının hava çıkıs fanlarından alınan hava ve sürüntü örneklerinde COVID-19 pozitif bulunmustur. Bu durum "hava yolu ile bulașa ișaret ediyor olabilir" seklinde yorumlanmıștır ${ }^{[15]}$. Cin'de semptomatik bir hastanın kapısının önünden birkac kez geçen, hastayla bașka herhangi bir teması olmayan bir kișinin hava yolu bula\$s1 açısından kanıt sağladığı bildirilmiștir ${ }^{[16]}$. Van Doremalen ve arkadașları tarafından yapilan bir calıșmada, SARS-CoV-2 ve SARS-CoV-1'in aerosollerde ve farklı yüzeylerdeki stabilitesi incelenmiștir. SARS-CoV-2'nin aerosollerde üc saat süreyle canlı kaldığı ve SARS-CoV-2 ve SARS-
CoV-1'in aerosollerdeki yarı ömrünün benzer olup ortalama 1.1-1.2 saat olduğu bulunmuștur ${ }^{[17]}$. Sonuc olarak her iki virüsün havayla bulaș açısından benzer karakteristikler tașıdığı yorumu yapilmıștır. SARS-CoV-2'nin havada 3 saat canl kalabilmesi temelinde maruziyet, inhalasyon ve infeksiyonun dakikalar ya da birkaç saat içinde, kaynağa yakın bir yerde veya kaynağın daha uzağında meydana gelebileceği ileri sürülmüștür ${ }^{[17]}$.

Genel olarak damlacık bulașını önlemek için iki metre güvenli zon kabul edilmektedir, ancak bunu destekleyecek karșlaștırmalı bir çalıșma yoktur ${ }^{[18]}$. Wells 1934 yılında buharlașma-düșme eğrisini dikkate alarak, büyük damlacıkların kaynaktan horizontal olarak iki metrelik mesafe içindeki alana düșeceklerini varsaymıștır ${ }^{[19]}$. Ancak bu varsayım, o tarihteki teknoloji ile, günümüze göre basit hesaplamalar ve yetersiz veri kullanilarak ileri sürülmüștür. Xie ve arkadașlarının 2007 yılında yapmıș olduğu bir çalıșmada, 60-100 $\mu \mathrm{m}$ arasındaki büyük damlacıkların, akımın hızına ve rölatif neme bağlı olarak hapșırma simülasyonu ile $50 \mathrm{~m} / \mathrm{s}$ hız ile altı metre uzağa kadar 0.12 saniye içinde, öksürük simülasyonu ile daha büyük damlacıkların $10 \mathrm{~m} / \mathrm{s}$ hızla iki metre uzağa kadar 0.2 saniye içinde, ekshalasyonla $1 \mathrm{~m} / \mathrm{s}$ hıla büyük damlacıkların horizontal olarak bir metre uzağa kadar bir saniye içinde gidebilecekleri gösterilmiștir [20]

Solunum yolu infeksiyonu olan biri öksürdüğünde veya hapşırdığında patojen tașıyan farklı büyüklüklerde bir damlacık bulutu ortaya çıtı̆̆1 ve damlacıkların kaynaktan 7-8 m uzağa taș1nabildiği bildirilmiștir (Șekil 4) ${ }^{[21]}$. Papineni ve Rosenthal (1997), beș gönüllüyle yaptıkları calișmada insan ekspiratuvar aktivitelerinde olușan partiküllerin \%80-90'ının 1 mm'den kücuuk aerosol seklinde olduğunu göstermișlerdir. Aynı calıșmada en yüksek aerosol dansitesinin öksürme ile, en düșük nazal nefes alıp verme ile oluștuğu bildirilmiștir ${ }^{[22]}$.

Damlacıkların bir kısmı akım yönü boyunca düserek yuizeyleri kontamine edebilir. Kalanlar hareket eden bulut içinde kalır ve kümelenirler. Sonuçta bulutun hareket ve bütünlüğü azalmaya bașlar ve bulut içinde kalan damlaciklarda buharlașma meydana gelir; havalandırma ve klima sistemleri tarafından olușturulan hava akım paternlerini takip eden havada saatlerce asılı kala- 


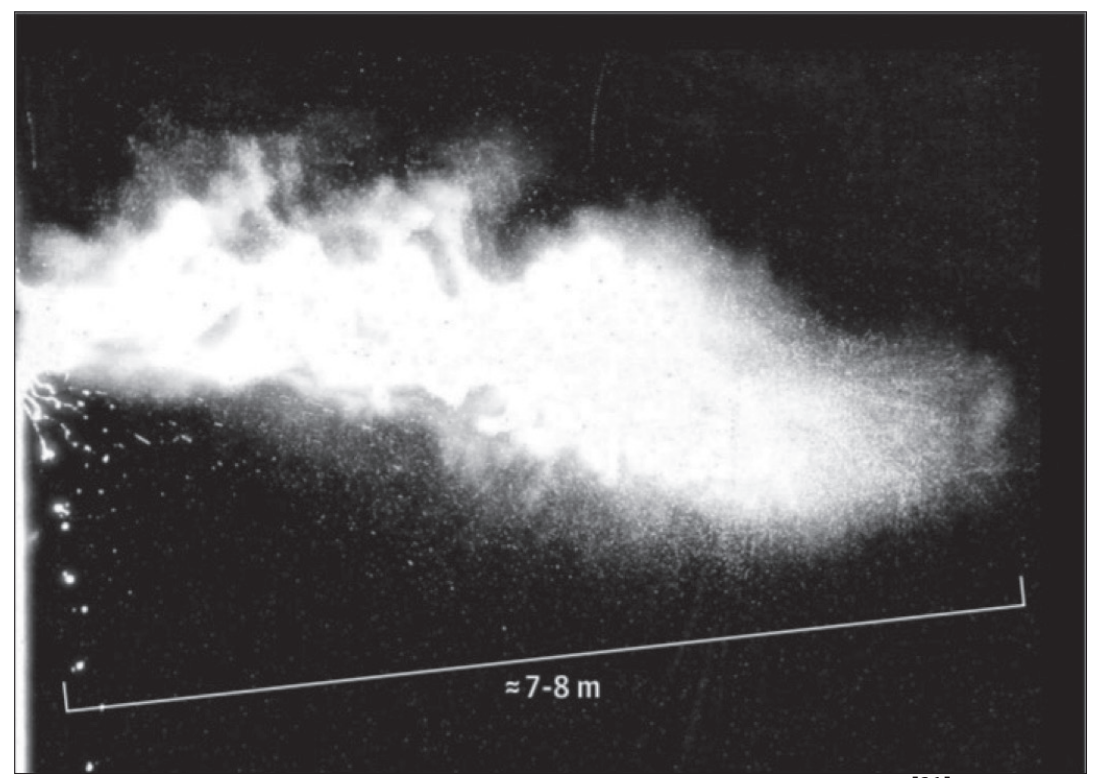

Şekil 4. Hapşırma eyleminden sonra oluşan multifaz türbülans gaz bulutu ${ }^{[21]}$.

bilen damlacık cekirdekleri olușur. Buharlașmanın derecesi ve oranı ortam isısına ve neme bağl1$\mathrm{d}_{1}{ }^{[21,23]}$.

Yüzey kontaminasyonu ve havada bulunma ile ilgili olarak genetik materyal ya da canlı virüsün respiratuar sekresyonlar, vücut sıvıları, boğaz sürüntüsü, anal sürüntüler, konjunktiva sürüntüleri, kan, balgam, gayta ve idrarda varlığı gösterilmiștir. Yine virüsün genetik materyali COVID-19 hastaları tarafından kullanilan tuvaletlerde, hastanede hemșire odalarının havasında, yüzeylerde, ventilatörlerin hava cıkıșlarında, hava yolu izolasyon odalarının ve genel servislerdeki diğer hasta odalarının havasında saptanmıstır ${ }^{[20,24-30] .}$ Singapur'da yapılan bir calıșmada, saatte $12 \mathrm{kez}$ hava değișimi olmasına rağmen hava yolu izolasyon odalarında 1.8-3.4 viral RNA kopya içeren SARS-CoV-2 partikülleri (> $4 \mu \mathrm{m}$ ve $1-4$ $\mu \mathrm{m})$ bulunmustur ${ }^{[27]}$. Singapur'da bir hasta odasının hava cıkıșından alınan sürüntü örneklerinde SARS-CoV-2 genetik materyalinin pozitif olduğu bildirilmiștir. Yazarlar bu bulgunun virüs içeren küçük aerosollerin hava akımı ile yer değiștirdiğine ve hava çkıșlarında biriktiğine ișaret ettiğini bildirmișlerdir $^{[5]}$. SARS-CoV-2 RNA'nın havadaki pik konsantrasyonlarının 0.25-1.0 $\mu \mathrm{m}$ ve $>2.5$ $\mu \mathrm{m}$ çapında olduğu saptanmıștır. Elde edilen bulgular virüs içeren aerosollerin, havada uzun süre asılı kalabileceğine ve inhale edilebileceğine ișaret ediyor olabilir ${ }^{[31]}$.

Aerosol veya damlacık cekirdeklerinin olușumundan sonraki nokta aerosol içinde virüsün infektivitesinin ne kadar süre devam ettiği ile ilgilidir. Havada ve yüzeylerde SARS-CoV-2'nin canlı kalabildiği deneysel olarak gösterilmistirir ${ }^{[32]}$. Fears ve arkadașları tarafından deneysel olarak gerçekleștirilen bir çalısmada SARS-CoV-2 aerosolize edilmiștir. Bulgular inhale edilebilir aerosollerde infektivite ve virion bütünlüğünün 16 saate kadar kaldığını göstermiștir (Sekil 5) ${ }^{[33]}$. Smither ve arkadașları tarafından yapılan bir calıșmada da SARS-CoV-2'nin İngiltere varyantının deneysel koșullarda yapay tükürük ve hücre kültürü kullanılarak aerosollerde canlı kalabildiği rapor edilmiștir ${ }^{[34]}$.

Son olarak COVID-19 hastalarının izlendiği servislerde havada canlı SARS-CoV-2 varlığı hücre kültürü yöntemiyle gösterilmiștir ${ }^{[28]}$.

Kim ve arkadașları tarafından gelincikler kullanılarak yapılan bir deneyde, gelinciklerden biri SARS-CoV-2 ile infekte edilmis, aynı ortama koyulan ve infekte gelincikle direkt temas eden gelinciklerde temas sonrası ikinci günde SARSCoV-2 tespit edilmiștir. Bir bariyer koyularak bariyerin diğer tarafına yerleștirilen naiv gelinciklerde de viral RNA pozitif saptanmıștır. Bu bulgunun 


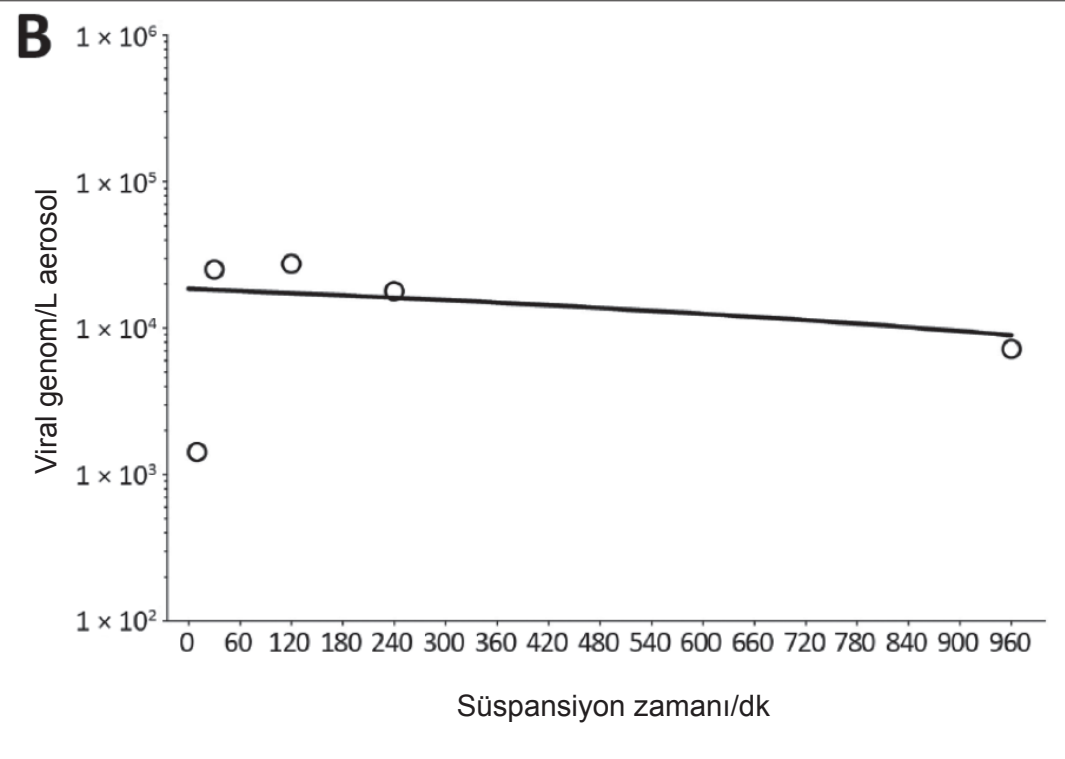

Şekil 5. SARS-CoV-2'nin aerosollerdeki infektivite ve virion bütünlüğü ${ }^{[33]}$.

hava yolu ile bulașa ișaret ediyor olabileceği yorumu yapılmıștır. Gelinciklerde akut bronșiolitle birlikte nazal sürüntü, trakea, akciğer ve barsakta viral antijen varlığı tespit edilmiștir ${ }^{[35]}$.

Richard ve arkadașları tarafından yine gelincikler üzerinde yapılan bir diğer calıșmada da SARS-CoV-2'nin temas ve hava yolu ile bulașabileceği gösterilmiștir. Ancak yazarlar iki ayrı kutuya koyulan gelincikler arasındaki mesafenin 10 $\mathrm{cm}$ olması nedeniyle bulașin aerosolle mi yoksa damlacıkla mı olduğunu ayırt edemediklerini belirtmislerdir ${ }^{[36]}$.

Bulaș olması için üçüncü basamak, hedef dokulara yeterince viral yük içeren aerosolün ulașabilmesidir $^{[37]}$. Bu konuda bulașın bildirildiğ epidemiyolojik çalıșmaların kanıt olarak kabul edilebileceği iddia edilmektedir. Bu yazıda aerosolle bulaș olabileceği iddia edilen çalıșmalardan bir kısmı ele alınmıștır. Cin'de 3 Subat'ta semptomatik bir hastanın kapısından birkac kez geçen fakat direkt teması olmayan bir kisiye daha sonra COVID-19 tanısı koyulması hava yolu bulașı olabileceği seklinde yorumlanmıștır ${ }^{[16]}$

$\mathrm{Lu}$ ve arkadașları calıșmalarında üc ailenin (A, B, ve C) 24 Ocak 2020'de yan yana üc masada öğle yemeği yediği, bu masalarda oturan 10 kiside (indeks vaka da dahil olmak üzere) COVID saptandığı bildirilmiștir. Garsonlar ya da diğer 15 masadaki 68 müșteriden infekte olan rapor edilmemiștir. Yazarlar tarafından bulașın sadece damlackkla olamayacağı, indeks vaka ile daha sonra infekte olan müsterilerden bir kısmı arasındaki mesafenin iki metreden daha uzun olduğu (bir müsteride 4.5 metre) kalabalık ve kötui havalandırması olan yerlerde aerosol bulașı olabileceği bildirilmiștir (Șekil 6). Ancak damlacıkların klimadan gelen güçlü hava akımı yoluyla $C$ masasından A'ya, oradan B'ye, sonra tekrar C'ye tașınmıs olabileceği de rapor edilmiștir ${ }^{[38]}$.

Cin'de Shen ve arkadașları tarafından yayımlanan bir raporda Zheijang'da bir Budist tapınağına ibadet etmek için gidenler arasında, otobüste bulaș olduğu düșünülen bir salgın bildirilmiștir. Seyahat her iki yöne yaklașı 50 dakika sürmüs, ibadet sırasında ise coğunlukla bina dıșında olmak üzere 150 dakika geçirilmiștir. Birinci otobüste 60, ikinci otobüste 67 kiși seyahat etmiș, dönüste yolculardan otobüs ya da yer değiștiren olmadığı rapor edilmiștir. Birinci otobüste seyahat sonrası COVID-19 vakasına rastlanmamıștır. Seyahatten sonra ikinci otobuiste seyahat edenlerde yolculuk sirasında semptomu olmayan bir kiși kaynaklı 23 COVID-19 vakası tespit edilmiștir. Atak rölatif riski birinci otobüse göre 41.5 kat daha fazla bulunmustur. İndeks vakaya yakın oturanlarda uzaktakilere göre istatistiksel olarak artmıs risk saptanmamıștır. Yazarlar bu bulgunun virüsün kıs- 


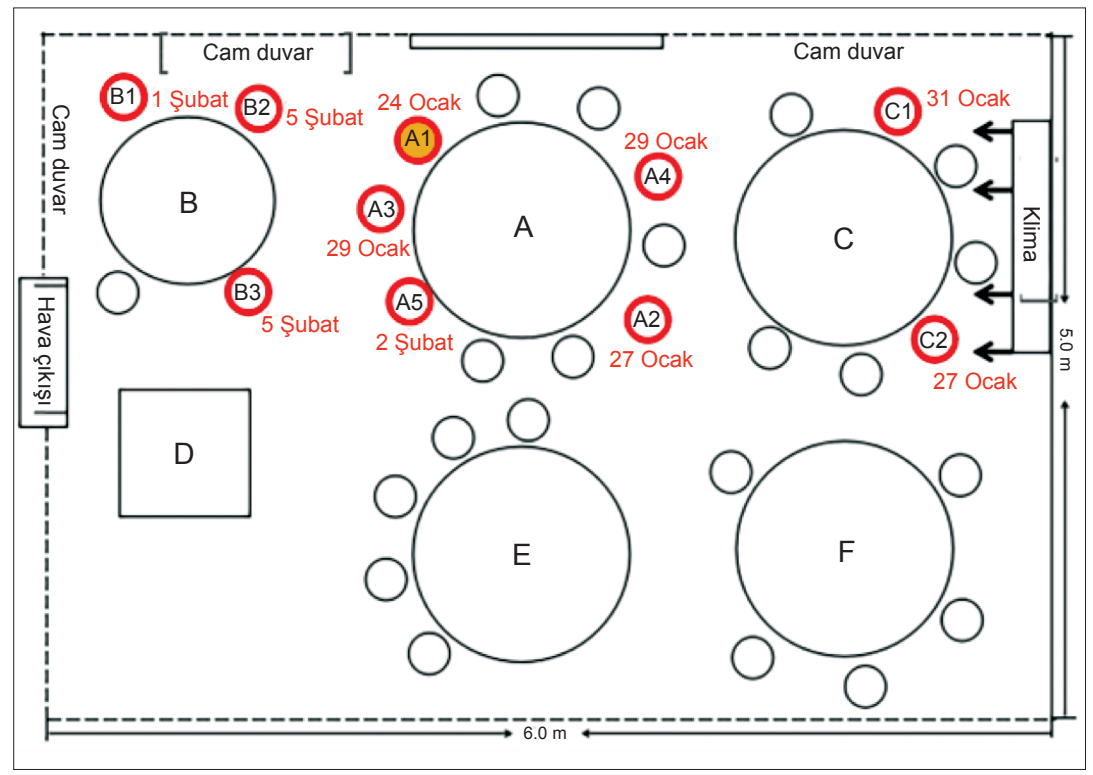

Şekil 6. Oturma düzeni (38 numaralı kaynaktan değiştirilerek alınmıştır).

men de olsa hava yolu ile bulașına ișaret ettiğini ve belirgin derecede yüksek atak oranını açılayabileceğini belirtmișlerdir (Sekil 7) ${ }^{[39]}$.

"Uzak mesafelerde hava ile bulas olduğunun epidemiyolojik olarak kanıtı" aerosol ile bulas için güçlü bir kanıt olușturmaktadır. Eğer COVID-19 sadece yakın temas ve damlacıkla bulașıyor olsaydı, indeks vakaya yakın oturan kișilerde, yani yüksek riskli bölgede daha fazla infekte vaka görülmesi gerektiği belirtilmiștir. İndeks vakada seyahat sırasinda semptom olmaması, nefes alı verme ile semptomatik olmadan önce sekonder vakalara yol açtığını göstermektedir ${ }^{[40,41]}$.

Hammer ve arkadasları tarafından, ABD'de bir koro calıșmasına katılanlar arasında yüksek COVID-19 atak oranı görülduuğü rapor edilmiștir. İndeks vakada semptom 7 Mart'ta bașlamıs ve bu kiși 10 Mart'ta koro çalıșmasına katılmıștır. Atak oranı doğrulanmıs vakalar dikkate alındığında $\% 53.3$, tüm vakalar dikkate alındığında \%86.7 olarak bulunmuștur ${ }^{[42]}$. Diğer kümelenmelere göre atak oranının daha yüksek olması süper bulastırıcı bir durum olduğunu düșündürmüștür ${ }^{[43,44]}$. Maruziyet ile hastalık bașlangıcı arasındaki ortalama süre üc gün olarak bildirilmiștir. Koro üyeleri arasında yakın temasla damlacık yoluyla bulas ya da cansız yüzeylerden geçișle bulaș söz konusu olabileceği rapor edilmis, ayrıca sarkı söylemenin bulașa katkıda bulunmus olabileceğine dikkat çekilmiștir $^{[17]}$. Konușma sırasında aerosol saçılım oranı yüksek ses ile koreledir. Süper bulastıtıC1 olarak adlandırılan bazı kișilerin diğerlerinden daha fazla partikül saçılımına yol açtığı ve süper bulas durumlarına katkıda bulunduğu hipotezi ileri sürülmüștür ${ }^{[45]}$.

Tang ve arkadașlarının çalısmasında aerosolle bulas için kanıt değerleri derecelendirildiğinde, SARS-CoV-2 için Jones ve Brosseau kriterlerine göre 9 üzerinden 8 değeri bulunmuștur ${ }^{[46,47]}$. Aerosol olușumu ile ilgili 3 üzerinden 3 , cevre kosullarında virüsün canlllığını devam ettirebilmesi ile ilgili 3 üzerinden 2 , hedef dokulara ulașma ile ilgili 3 üzerinden 3 puan verilmistir. Bu puanlamaya göre SARS-CoV-2 tüberkülozla aynı grupta yer almaktadır. Aerosol bulașına karșı cıkan bilim insanlarının iddiası ise aerosolle bulaștı̆̆1 rapor edilen epidemiyolojik durumlarda damlacik ya da temasla bulaşın ekarte edilemeyeceği șeklindedir ${ }^{[48]}$.

Sonuc olarak DSÖ tarafından da güncellendiği gibi kapalı, kalabalık ve havalandırması kötü olan yerlerde aerosolle bulas olabilir.

Özellikle dıșarıdan temiz hava almadan ısınma veya soğutma amaçlı mekan içindeki havanın resirkülasyonu SARS-COV-2 bulașı açısından önemli risk olusturmaktadır. Mevcut kanıtlar virüsün sadece temas ve damlacık ile değil hava yolu ile de bulașabileceğini göstermektedir. 


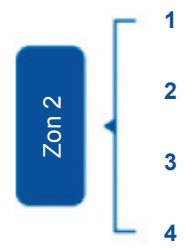

4

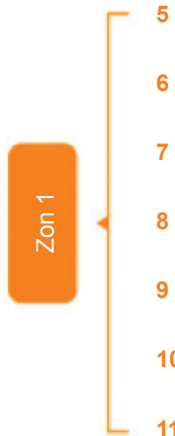

N
VO

VO
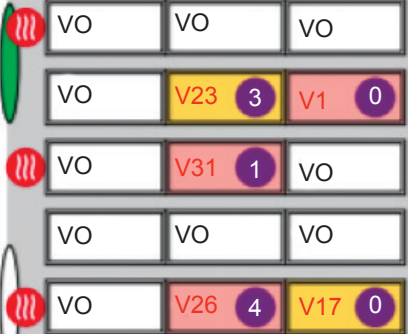

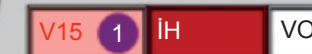
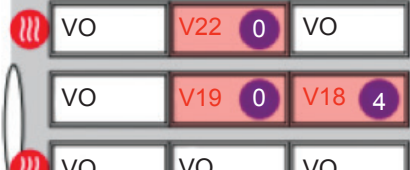

\begin{tabular}{|l|l|l|}
\hline VO & VO & VO \\
\hline
\end{tabular}

\begin{tabular}{|l|l|l|ll|l}
\hline Vo & V16 & 1 & v30 & 0 \\
\hline
\end{tabular}

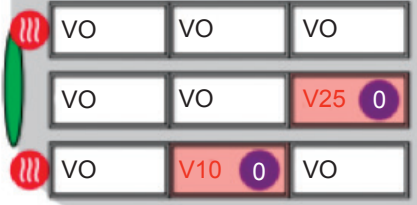

Ón pencere
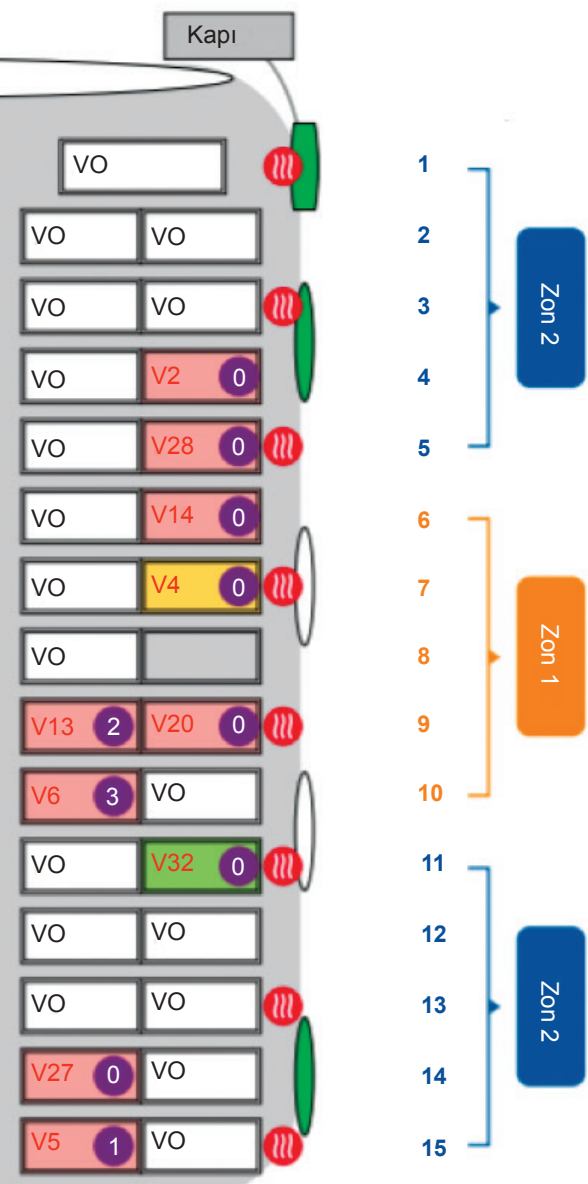
Vaka
olmayan Asemptomatik vaka $\square$ Hafif vaka $\square$ Orta vaka

Indeks hasta

Şekil 7. Otobüste oturma düzeninin şematik görünümü (39 numaralı kaynaktan değiştirilerek alınmıştır).

\section{ÇIKAR ÇATIŞMASI}

Yazar bu makale ile ilgili herhangi bir çkar çatısması bildirmemiștir.

\section{KAYNAKLAR}

1. World Health Organization (WHO). Available from: https://www.who.int/emergencies/diseases/novel-coronavirus-2019.

2. Jayawera $M$, Perera H, Gunawardana B, Manatunge J. Transmission of COVID-19 virus by droplets and aerosols: A critical review on the unresolved dichotomy. Environ Res 2020;188:109819.
3. World Health Organization (WHO). Infection prevention and control of epidemic- and pandemic-prone acute respiratory infections in health care. Geneva: World Health Organization; 2014. Erişim tarihi: 08.12.2020. Available from: https://apps.who.int/iris/bitstream/handle/10665/112656/9789241507134_eng.pdf?sequenc

4. Centers for Disease Control and Prevention (CDC). Erişim tarihi: 08.12.2020. Available from: https://www.cdc.gov/ infectioncontrol/guidelines/isolation/scientific-review.html

5. Gralton J, Tovey E, McLaws ML, Rawlinson WD. The role of particle size in aerosolised pathogen transmission: a review. J Infect 2011;62:1-13. 
6. Nicas M, Nazaroff WW, Hubbard A. Toward understanding the risk of secondary airborne infection: emission of respirable pathogens. J Occup Environ Hyg 2005;2:143-54.

7. Tellier R. Aerosol transmission of influenza a virus: a review of new studies. J $R$ Soc Interface 2009;6:783-90.

8. da Silva MG. An analysis of the transmission modes of COVID-19 in light of the concepts of Indoor Air Quality. REHVA 2020;57:45-54.

9. Wei J, Li Y. Enhanced spread of expiratory droplets by turbulence in a cough jet. Build Environ 2015;93:86-96.

10. Henrique A. Airborne transmission of COVID-19 measures to be taken indoors. HSE Seminar. Erişim tarihi: 17.11.2020. Available from: https://indico.cern.ch/event/968258/

11. World Health Organization press conference 11.02.2020. file:///C:/Users/user/Desktop/COVID-Aerosol/who-audio-emergencies-coronavirus-full-press-conference-11feb2020-final.pdf. Erişim tarihi: 08.12.2020.

12. https://twitter.com/who/status/1243972193169616898 Erişim tarihi: 08.12.2020.

13. Transmission of SARS-CoV-2: implications for infection prevention precautions: scientific brief, 09 July 2020. Available from: https://apps.who.int/iris/handle/10665/333114

14. Morawska L, Cao J. Airborne transmission of SARSCoV-2: The world should face the reality. Environ Int 2020;139:105730.

15. Ong SWX, Tan YK, Chia PY, Lee TH, Ng OT, Wong MSY, et al. PhD air, Surface environmental, and personal protective equipment contamination by severe acute respiratory syndrome Coronavirus 2 (SARS-CoV-2) from a symptomatic patient. JAMA 2020;323:1610-2.

16. Wang J, Du G. COVID-19 may transmit through aerosol. Ir J Med Sci 2020;189:1143-4.

17. van Doremalen $N$, Morris $D H$, Hollbrook MG, Gamble A, Williamson BN, Tamin A, et al. Aerosol and surface stability of SARS-CoV-2 as compared with SARS-CoV-1. N Engl I Med 2020;382(16):1564-7.

18. Bourouiba L. Images in clinical medicine. A sneeze. N Engl J Med 2016;375(8):e15.

19. Wells WF. On air-borne infection: study II. Droplets and droplet nuclei. Am J Epidemiol 1934;20:611-8.

20. Xie $X$, Li Y, Chwang AT, Ho PL, Seto WH. How far droplets can move in indoor environments-revisiting the Wells evaporation-falling curve. Indoor Air 2007;1 7:211-25.

21. Bourouiba L. Turbulent gas clouds and respiratory pathogen emissions potential implications for reducing transmission of COVID-19. JAMA 2020;323:1837-8.

22. Papineni RS, Rosenthal FS. The size distribution of droplets in the exhaled breath of healthy human subjects. J Aerosol Med 1997;10:105-16.

23. Loh NHW, Tan Y, Taculod I, Gorospe B, Teope AS, Somani J, et al. The impact of high-flow nasal cannula (HFNC) on coughing distance: implications on its use during the novel coronavirus disease outbreak. Can J Anesth 2020;67:893-4.
24. Holshue ML, DeBolt C, Lindquist S, Lofy KH, Wiesman J, Bruce $H$, et al. First case of 2019 novel Coronavirus in the United States. N Engl J Med 2020;382:929-36.

25. Guan WJ, Ni ZY, Hu Y, Liang WH, Ou CQ, He JX, et al. Clinical characteristics of Coronavirus disease 2019 in China. N Engl J Med 2020;30;382:1708-20.

26. Wölfel $R$, Corman VM, Guggemos W, Seilmaier $M$, Zange $S$, Müller MA, et al. Virological assessment of hospitalized patients with COVID-2019. Nature 2020,581:465-9.

27. Chia PY, Coleman KK, Tan YK, Seilmaier M, Zange S, Müller $M A$, et al. Detection of air and surface contamination by SARS-CoV-2 in hospital rooms of infected patients. Nat Commun 2020;11:2800.

28. Santarpia JL, Rivera DN, Herrera VL, Morwitzer MJ, Creager HM, Santarpia GW, et al. Aerosol and surface contamination of SARS-COV-2 observed in quarantine and isolation care. Sci Rep 2020;10:12732.

29. Ding Z, Qian H, Xu B, Huang Y, Miao T, Yen HL, et al. Toilets dominate environmental detection of SARSCoV-2 virus in a hospital. Sci Total Environ 2020;753:141710.

30. Jiang $Y$, Wang $H$, Chen $Y, H e$ J, Chen L, Liu Y, et al. Clinical data on hospital environmental hygiene monitoring and medical staffs protection during the Coronavirus disease 2019 outbreak. medRxiv 2020. E pub 2020 March 02.

31. Liu Y, Ning Z, Chen Y, Guo M, Liu Y, Gali NK, et al. Aerodynamic analysis of SARS-CoV-2 in twoWuhan hospitals. Nature 2020;582:557-60.

32. Chin A, Chu J, Perera M, Hui KPY, Yen HL, Chan MCW, et al. Stability of SARS-CoV-2 in different environmental conditions. Lancet Microbe 2020;1:e10.

33. Fears $A C$, Klimstra $W B$, Duprex $P$, Hartman $A$, Weaver SC. Persistence of severe acute respiratory syndrome Coronavirus 2 in aerosol suspensions. Emerg Infect Dis 2020;26:2168-71.

34. Smither SJ, Eastaugh LS, Findlay JS, Lever MS. Experimental aerosol survival of SARS-CoV-2 in artificial saliva and tissue culture media at medium and high humidity. Emerg Microbes Infect 2020;9:1415-17.

35. Kim YI, Kim SG, Kim SM, Kim EH, Park SI, Yu KM, et al. Infection and rapid transmission of SARS-CoV-2 in ferrets. Cell Host Microbe 2020;27:704-9.

36. Richard $M$, Kok $A$, de Meulder D, Bestebroer TM, Lamers MM, Okba NMA, et al. SARS-CoV-2 is transmitted via contact and via the air between ferrets. Nat Commun 2020;11:3496.

37. Jones RM, Brosseau LM. Aerosol transmission of infectious disease. J Occup Environ Med 2015;57:501-8.

38. Lu J, Gu J, Li K, Xu C, Su W, Lai Z, et al. COVID-19 outbreak associated with air conditioning in restaurant, Guangzhou, China. Emerg Infect Dis 2020;26:1628-31.

39. Shen Y, Li C, Dong H, Wang Z, Martinez L, Sun Z. Community outbreak investigation of SARS-CoV-2 transmission among bus riders in Eastern China. JAMA Intern Med 2020;e205225. 
40. Arons MM, Hatfield KM, Reddy SC, Kimball A, James A, Jacobs JR. Public Health-Seattle and King County and CDC COVID-19 Investigation Team. Presymptomatic SARS CoV-2 infections and transmission in a skilled nursing facility. N Engl J Med 2020;382:2081-90.

41. He X, Lau EHY, Wu P, Deng X, Wang I, Hao X, et al. Temporal dynamics in viral shedding and transmissibility of $\mathrm{CO}$ VID-19. Nat Med 2020;26:672-5.

42. Hamner L, Dubbel P, Capron I, Ross A, Jordan A, Lee J, et al. High SARS-CoV-2 attack rate following exposure at a choir practice - Skagit County, Washington, March 2020. MMWR 2020;69:606-10.

43. McMichael TM, Currie DW, Clark S, Pogosjans S, Kay M, Schwartz NG, et al. Epidemiology of COVID-19 in a longterm care facility in King County, Washington. N Engl J Med 2020;382:2005-11.

44. Ghinai I, Woods S, Ritger KA, McPherson TD, Black SR, Sparrow $L$, et al. Community transmission of SARS-CoV-2 at two family gatherings - Chicago, Illinois, February-March 2020. MMWR Morb Mortal Wkly Rep 2020;69:446-50.

45. Asadi S, Wexler AS, Cappa CD, Barreda S, Bouvier NM, Ristenpart WD. Aerosol emission and superemission during human speech increase with voice loudness. Sci Rep 2019:9:2348.
46. Tang S, Mao Y, Jones RM, Tan Q, Ji JS, Lia N, et al. Aerosol transmission of SARS-CoV-2? Evidence, prevention and control. Environ Int 2020;144:106039.

47. Jones RM, Brosseau LM. Aerosol transmission of infectious disease. J Occup Environ Med 2015;57:501-8.

48. Sommerstein R, Fux CA, Vuichard-Gysin D, Abbas $M$, Marschall J. Risk of SARS-CoV-2 transmission by aerosols, the rational use of masks, and protection of healthcare workers from COVID-19. Antimicrob Resist Infect Control 2020;9:100

\section{Yazıșma Adresi/Address for Correspondence}

Prof. Dr. Gül Ruhsar YILMAZ

Süleyman Demirel Üniversitesi Tıp Fakültesi,

İnfeksiyon Hastalıkları ve

Klinik Mikrobiyoloji Anabilim Dalı, Isparta-Türkiye

E-posta: ruhsar6@yahoo.com 